\title{
Physicochemical and Thermal Properties of Consciousness Energy Healing Treated Hydroxypropyl $\beta$-Cyclodextrin
}

\author{
Nayak G, Trivedi MK, Branton A, Trivedi D and Jana $S^{*}$ \\ Trivedi Global, Inc., Henderson, USA \\ Trivedi Science Research Laboratory Pvt. Ltd.,Bhopal, India
}

*Corresponding author: Snehasis Jana, Trivedi Science Research Laboratory Pvt. Ltd., Bhopal, India, Tel: +91-022-25811234; Email: publication@trivedieffect.com

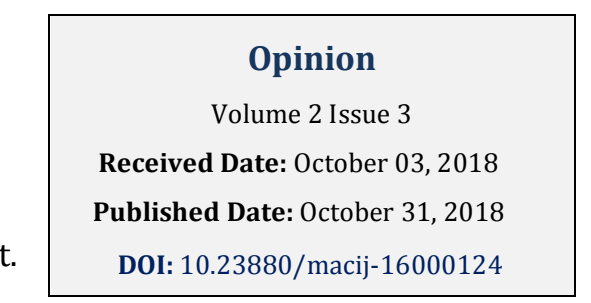

\section{Abstract}

Hydroxypropyl $\beta$-Cyclodextrin (HP $\beta$-CD) is having a lot of applications in the food, pharmaceutical, nutraceutical, chemical industries, also in the field of environmental and agriculture engineering. This study evaluated the influence of the Trivedi Effect ${ }^{\circledR}$ on the physicochemical and thermal properties of HP $\beta$-CD using modern analytical techniques. The test sample was divided into control and treated parts. The control part did not receive the Biofield Energy Treatment; whereas, the treated part was received the Biofield Energy Treatment remotely by a famous Biofield Energy Healer, Gopal Nayak. The particle size values were decreased by $2.16 \%\left(d_{10}\right), 0.65 \%\left(d_{50}\right), 1.22 \%\left(d_{90}\right)$, and $1 \%\{D(4,3)\}$; thus, the specific surface area was increased by $1.27 \%$ in the treated sample compared to the control sample. The latent heat of fusion of the treated sample was significantly increased by $41.32 \%$ compared with the control sample. The total weight loss was decreased; however, the residue amount was significantly increased by $15.53 \%$ of the treated sample compared to the control sample. The results indicated that the Biofield Energy Treatment produced a new form of HP $\beta$-CD, which may show better solubility, dissolution rate, absorption, bioavailability, and more thermal stability compared to the control sample. The treated sample would be more useful for the improvement of solubility of the lipophilic drugs, preparation of cholesterol free food products, weight loss supplements, etc.

Keywords: Hydroxypropyl $\beta$-Cyclodextrin; The Trivedi Effect ${ }^{\circledR}$; Consciousness Energy Healing Treatment; Complementary and Alternative Medicine; Particle size; Surface area; PXRD; DSC; TGA/DTG

Abbreviations: HP $\beta$-CD: Hydroxypropyl $\beta$ cyclodextrin, NCCAM: National Center for Complementary and Alternative Medicine, NIH: National Institutes of Health; CAM: Complementary and Alternative Medicine,
PSA: Particle size analysis; PXRD: Powder X-ray diffraction, DSC: differential scanning calorimetry; TGA: Thermo gravimetric analysis; DTG: Differential thermo gravimetric analysis. 


\section{Medicinal \& Analytical Chemistry International Journal}

\section{Introduction}

Hydroxypropyl $\beta$-cyclodextrin (HP $\beta$-CD) is produced from starch by the enzymatic reaction. HP $\beta$-CD is commonly used in food, pharmaceutical, nutraceutical, chemical industries, also in the field of environmental, and agriculture engineering [1]. HP $\beta$-CD is amphoteric in nature, i.e., hydrophilic outside and hydrophobic inside. It is very easy to form complexes with hydrophobic (lipophilic) compounds. It forms intramolecular hydrogen bonding among the hydroxyl groups of neighboring glucopyranose units, which is a unique structural feature of HP $\beta$-CD owe their stability. This unique quality of HP $\beta$-CD improves the solubility, bioavailability, and membrane permeability of many pharmaceutical and nutraceutical compounds [1-3]. It is used for the preparation of weight loss supplements, cholesterol-free products, alcohol powder, aerosols, and anti-obesity medications in the food, nutraceutical, and pharmaceutical industries. The surface-active properties of HP $\beta$-CD may lead to its use as an emulsifying agent [46]. It can be used to stabilize volatile or unstable compounds, reduce the unwanted tastes and odour, deep encolour, improve light stability, and increase water solubility [1,7]. In the analytical chemistry, it is also used in the chiral HPLC columns for the separation of chiral compounds, and is also the core ingredient in air freshener products which trap bad odour $[2,8]$. The solubility of natural cyclodextrin is very poor; even the chemically modified cyclodextrin like HP $\beta$-CD can only achieves a $50 \%(\mathrm{w} / \mathrm{v})$ concentration in water [2].

The Trivedi Effect ${ }^{\circledR}$-Biofield Energy Healing Treatment has shown the significant influence on the crystallite size, particle size, surface area, solubility, bioavailability, and thermal properties of the pharmaceutical and nutraceutical compounds [9-12]. The Trivedi Effect ${ }^{\circledR}$ is a natural and only scientifically proven phenomenon in which a person can harness this inherently intelligent energy from the Universe and transmit it anywhere on the planet through the possible mediation of neutrinos [13]. Inside the body, there is a natural process of continuous movement of the electrically charged particles like ions, cells, blood flow, heart movement, etc. This mutants inside the body generate unique para-dimensional electromagnetic field around the body of the living organism known as the "Biofield". The Biofield based Energy Therapies have been accepted all over the world and reported in many scientific journals with significantly beneficial outcomes against various disease conditions $[14,15]$. The National Center for Complementary and Alternative Medicine (NCCAM) and National Institutes of
Health (NIH) recommend and included the Energy therapy under Complementary and Alternative Medicine (CAM) category along with homeopathy, Ayurvedic medicine, Chinese herbs and medicines, acupuncture, acupressure, yoga, meditation, Reiki, hypnotherapy, Tai Chi, Qi Gong, chiropractic/osteopathic manipulation, Rolfing, etc., which has been accepted by the most of the U.S.A. population [16,17]. Similarly, the Consciousness Energy Healing Treatment also showed significant performance in the different field of sciences, i.e., material science, organic chemistry, biotechnology, microbiology, agriculture, and medical science [18-23]. The significant results influenced the authors to evaluate the impact of the Trivedi Effect ${ }^{\circledR}$-Consciousness Energy Healing Treatment on HP $\beta$-CD sample using particle size analysis (PSA), powder X-ray diffraction (PXRD), differential scanning calorimetry (DSC) analytical techniques, and thermo gravimetric analysis (TGA)/Differential thermo gravimetric analysis (DTG).

\section{Materials and Methods}

\section{Chemicals and Reagents}

The Hydroxypropyl $\beta$-cyclodextrin (HP $\beta$-CD) powder was bought from Tokyo Chemical Industry Co. Ltd, Japan. Other chemicals used in the experiment were of analytical grade purchased from India.

\section{Consciousness Energy Healing Treatment Strategies}

The test sample HP $\beta$-CD was divided into control part and the Biofield Energy Treated part. The treated part was provided the Trivedi Effect ${ }^{\circledR}$-Consciousness Energy Healing Treatment remotely under standard laboratory conditions for 3 minutes by a famous Biofield Energy Healer, Gopal Nayak, India. However, the control part did not receive the Biofield Energy Treatment. But, the control sample was treated by a "sham" healer. The "sham" healer completely unaware of the Biofield Energy Treatment. After the treatment, the Biofield Energy Treated and untreated samples were kept in sealed conditions and characterized using PSA, PXRD, DSC, and TGA analytical techniques.

\section{Characterization}

Particle Size Analysis (PSA): The particle size analysis of HP $\beta$-CD powder sample was performed on Malvern Master sizer 2000, from the UK [24,25]. The PSA analysis of HP $\beta$-CD powder was executed to obtain the average particle size distribution. The calculations were done by using software Mastersizer Ver. 5.54.
Nayak G, et al. Physicochemical and Thermal Properties of Consciousness Energy Healing Treated Hydroxypropyl $\beta$-Cyclodextrin. Med \& Analy Chem Int J 2018, 2(3): 000124.
Copyright@ $\subseteq$ Nayak G, et al. 


\section{Medicinal \& Analytical Chemistry International Journal}

The percent change in particle size (d) for HP $\beta$-CD powder at below $10 \%$ level $\left(d_{10}\right), 50 \%$ level $\left(d_{50}\right), 90 \%$ level $\left(\mathrm{d}_{90}\right)$,and $\mathrm{D}(4,3)$ was calculated using the following equation 1 :

$$
\% \text { change in particle size }=\frac{\left[\mathrm{d}_{\text {Treated }}-\mathrm{d}_{\text {Control }}\right]}{\mathrm{d}_{\text {Control }}} \times 100 \text { (1) }
$$

Where $d_{\text {Control }}$ and $d_{\text {Treated }}$ are the particle size $(\mu \mathrm{m})$ for at below $10 \%$ level $\left(d_{10}\right), 50 \%$ level $\left(d_{50}\right), 90 \%$ level $\left(d_{90}\right)$, and $\mathrm{D}(4,3)$ the average mass-volume diameter of the control and the Biofield Energy Treated HP $\beta$-CD powder samples, respectively.

The percent change in surface area (S) was calculated using following the equation 2 :

$$
\% \text { change in surface area }=\frac{\left[\mathrm{S}_{\text {Treated }}-\mathrm{S}_{\text {Control }}\right]}{\mathrm{S}_{\text {Control }}} \times 100(2)
$$

Where $S_{\text {Control }}$ and $S_{\text {Treated }}$ are the surface area of the control and the Biofield Energy Treated HP $\beta$-CD sample, respectively.

Powder X-ray Diffraction (PXRD) Analysis: The PXRD analysis of HP $\beta$-CD power sample was performed with the help of Rigaku Mini Flex-II Desktop X-ray diffract meter (Japan) [26,27]. The average size of individual crystallites is generally calculated using the Scherrer's formula (3).

$$
\mathrm{G}=\mathrm{k} \lambda / \beta \cos \theta
$$

Where $\mathrm{k}$ is the equipment constant (0.94), $\mathrm{G}$ is the crystallite size in $\mathrm{nm}, \lambda$ is the radiation wavelength ( $0.154056 \mathrm{~nm}$ for K $\alpha 1$ emission), $\beta$ is the full-width at half maximum (FWHM), and $\theta$ is the Bragg angle [28].

Differential Scanning Calorimetry (DSC): The DSC analysis of HP $\beta$-CD powder sample was performed with the help of DSC Q200, TA instruments. The sample of $\sim 1$ $2 \mathrm{mg}$ was loaded to the aluminium sample pan at a heating rate of $10^{\circ} \mathrm{C} / \mathrm{min}$ from $30^{\circ} \mathrm{C}$ to $350^{\circ} \mathrm{C}[24,25]$. The $\%$ change in melting point $(\mathrm{T})$ was calculated using the following equation 4 :

$$
\% \text { change in melting point }=\frac{\left[\mathrm{T}_{\text {Treated }}-\mathrm{T}_{\text {Control }}\right]}{\mathrm{T}_{\text {Control }}} \times 100(4)
$$

Where $\mathrm{T}_{\text {Control }}$ and $\mathrm{T}_{\text {Treated }}$ are the melting point of the control and the Biofield Energy Treated HP $\beta$-CD powder sample, respectively. The $\%$ change in the latent heat of fusion $(\Delta \mathrm{H})$ was calculated using the following equation 5 :

$\%$ change in latent heat of fusion $=\frac{\left[\Delta \mathrm{H}_{\text {Treated }}-\Delta \mathrm{H}_{\text {Control }}\right]}{\Delta \mathrm{H}_{\text {Control }}} \times 100$

Where $\Delta \mathrm{H}_{\text {Control }}$ and $\Delta \mathrm{H}_{\text {Treated }}$ are the latent heat of fusion of the control and the Biofield Energy Treated HP $\beta$-CD powder sample, respectively.

Thermal Gravimetric Analysis (TGA)/ Differential Thermo Gravimetric Analysis (DTG): TGA/DTG thermograms of HP $\beta$-CD powder samples were obtained with the help of TGA Q50 TA instruments. The sample of 4-6 mg was loaded to the platinum crucible at a heating rate of $10^{\circ} \mathrm{C} / \mathrm{min}$ from $25^{\circ} \mathrm{C}$ to $1000^{\circ} \mathrm{C}$ with the recent literature $[24,25]$. The $\%$ change in weight loss (W) was calculated using the following equation 6 :

$$
\% \text { change in weight loss }=\frac{\left[\mathrm{W}_{\text {Treated }}-\mathrm{W}_{\text {Control }}\right]}{\mathrm{w}_{\text {Control }}} \times 100(6)
$$

Where $\mathrm{W}_{\text {Control }}$ and $\mathrm{W}_{\text {Treated }}$ are the weight loss of the control and Biofield Energy Treated HP $\beta$-CD powder sample, respectively. The $\%$ change in maximum thermal degradation temperature $\left(\mathrm{T}_{\max }\right)(\mathrm{M})$ was calculated using the following equation 7 :

$$
\% \text { change in } \operatorname{Tmax}(\mathrm{M})=\frac{\left[\mathrm{M}_{\text {Treated }}-\mathrm{M}_{\text {Control }}\right]}{\mathrm{M}_{\text {Control }}} \times 100(7)
$$

Where $\mathrm{M}_{\text {Control }}$ and $\mathrm{M}_{\text {Treated }}$ are the $\mathrm{T}_{\max }$ values of the control and the Biofield Energy Treated HP $\beta$-CD powder sample, respectively.

\section{Results and Discussion}

\section{Powder X-ray Diffraction (PXRD) Analysis}

The control and the Biofield Energy Treated HP $\beta$-CD samples did not show sharp and intense peaks in the respective XRD diffractograms (Figure 1). Therefore, it was concluded that both the samples were amorphous in nature and the Biofield Energy Treatment did not have any significant effect on the crystallinity pattern of the HP $\beta$-CD. 


\section{Medicinal \& Analytical Chemistry International Journal}

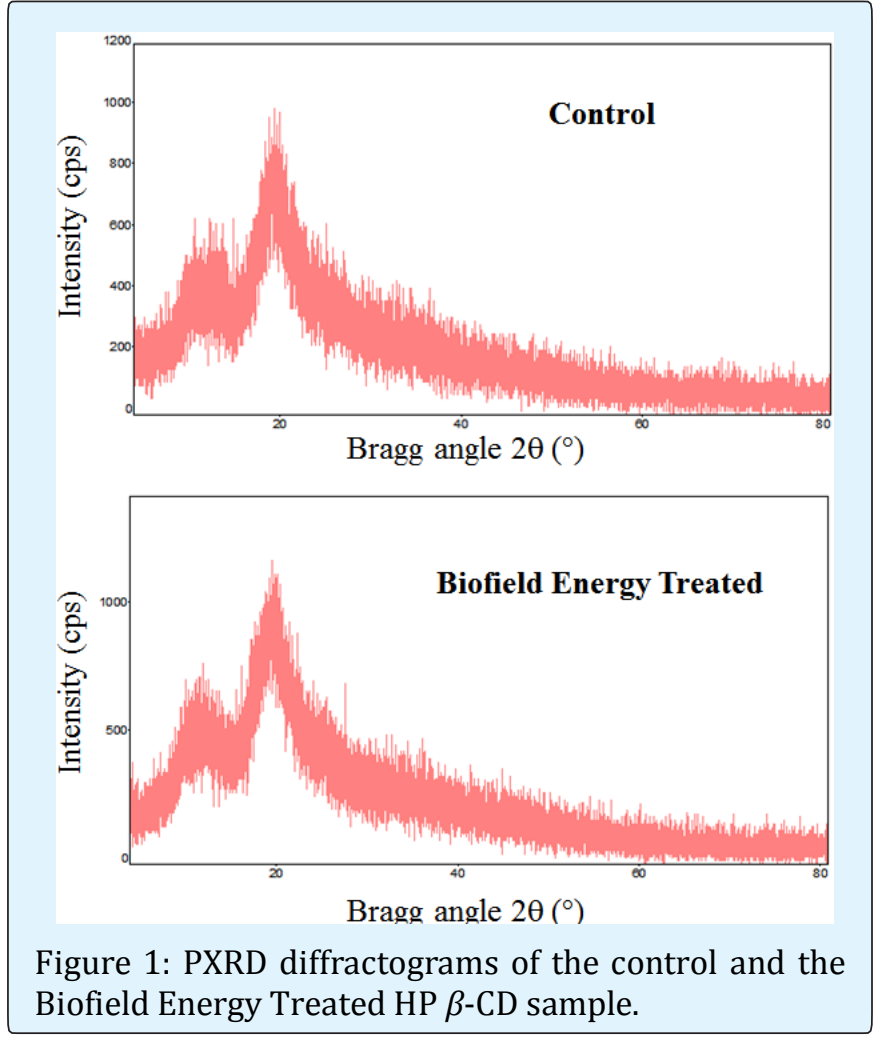

\section{Particle Size Analysis (PSA)}

The particle size data of both the control and the Biofield Energy Treated HP $\beta$-CD are presented in Table 1.
The particle sizes of the control sample at $d_{10}, d_{50}, d_{90}$, and D $(4,3)$ were $22.002 \mu \mathrm{m}, 77.295 \mu \mathrm{m}, 163.137 \mu \mathrm{m}$, and $86.032 \mu \mathrm{m}$, respectively. As well, the particle sizes of the treated sample at $d_{10}, d_{50}, d_{90}$, and $D(4,3)$ were 21.527 $\mu \mathrm{m}, 76.794 \mu \mathrm{m}, 161.148 \mu \mathrm{m}$, and $85.169 \mu \mathrm{m}$, respectively. The particle size values of the Biofield Energy Treated HP $\beta$-CD sample was decreased by $2.16 \%, 0.65 \%, 1.22 \%$, and $1 \%$ at $\mathrm{d}_{10}, \mathrm{~d}_{50}, \mathrm{~d}_{90}$, and $\mathrm{D}(4,3)$, respectively compared to the control sample (Table 1). The specific surface area of the treated HP $\beta$-CD sample $\left(0.16 \mathrm{~m}^{2} / \mathrm{g}\right)$ was increased by $1.27 \%$ compared with the control sample $\left(0.158 \mathrm{~m}^{2} / \mathrm{g}\right)$. The Consciousness Energy Healing Treatment might be acting like an external force to break the larger HP $\beta$-CD particles to the smaller one, resulted in the increase of the surface area. The particle size, shape, and surface area of a particle have the significant impact on the physicochemical and thermal properties of a pharmaceutical substance [29-31]. As per the literature data, the solubility profile of HP $\beta$-CD is $50 \%(\mathrm{w} / \mathrm{v})$ in water [2]. As the particle sizes were reduced and increased surface area in the Biofield Energy Treated HP $\beta$-CD sample compared to the control sample. Hence, the surface-active properties of the Biofield Energy Treated HP $\beta$-CD sample would be very high. The Biofield Energy Treated HP $\beta$-CD would be more useful to improve the quality drug delivery of the lipophilic drug, stabilize volatile and unstable compounds, weight loss supplements, preparation of cholesterol free food products, and other anti-obesity medication [1, 4-7] and for the other pharmaceutical and nutraceutical industries using it as a raw material.

\begin{tabular}{|c|c|c|c|c|c|}
\hline Parameter & $\mathbf{d}_{\mathbf{1 0}}(\boldsymbol{\mu m})$ & $\mathbf{d}_{\mathbf{5 0}}(\boldsymbol{\mu m})$ & $\mathbf{d}_{\mathbf{9 0}}(\boldsymbol{\mu m})$ & $\mathbf{D}(\mathbf{4}, \mathbf{3})(\boldsymbol{\mu m})$ & $\mathbf{S S A}\left(\mathbf{m}^{\mathbf{2}} / \mathbf{g}\right)$ \\
\hline Control & 22.002 & 77.295 & 163.137 & 86.032 & 0.158 \\
\hline Biofield Energy Treated & 21.527 & 76.794 & 161.148 & 85.169 & 0.16 \\
\hline Percent change* $\left.^{*} \%\right)$ & -2.16 & -0.65 & -1.22 & -1 & 1.27 \\
\hline
\end{tabular}

Table 1: Particle size distribution of the control and the Biofield Energy Treated HP $\beta$-CD sample. $\mathrm{d}_{10}, \mathrm{~d}_{50}$, and $\mathrm{d}_{90}$ : particle diameter corresponding to $10 \%, 50 \%$, and $90 \%$ of the cumulative distribution, $\mathrm{D}(4,3)$ : the average mass-volume diameter, and SSA: the specific surface area. *denotes the percentage change in the Particle size distribution of the Biofield Energy Treated HP $\beta$-CD sample with respect to the control sample.

\section{Differential Scanning Calorimetry (DSC) Analysis}

The control and the treated HP $\beta$-CD samples showed two endothermic peaks in the thermograms. The control HP $\beta$-CD sample showed the endothermic peaks at $99.84^{\circ} \mathrm{C}$ and $326.36^{\circ} \mathrm{C}$ (Figure 2). Similarly, the treated sample showed the endothermic peaks at $112.55^{\circ} \mathrm{C}$ and $323.92^{\circ} \mathrm{C}$ (Figure 2). The $1^{\text {st }}$ endothermic peak in the thermograms was due to the evaporation of the trapped water molecule from the sample; however, the $2^{\text {nd }}$ endothermic pick was due to the melting of HP $\beta$-CD sample. The experimental results were well matched with the literature data [32]. The evaporation temperature of the treated HP $\beta$-CD sample was significantly increased by $12.73 \%$ compared to the control sample (Table 2). However, the melting temperature of the treated sample slightly altered by $-0.75 \%$ compared with the control sample (Table 2). The latent heat of evaporation $\left(\Delta \mathrm{H}_{\text {evaporation }}\right)$ and latent heat of fusion $\left(\Delta \mathrm{H}_{\text {fusion }}\right)$ of the 
treated HP $\beta$-CDs ample were significantly altered by $18.08 \%$ and $41.32 \%$, respectively compared to the control sample (Table 2). The change in the molecular chains and the crystal structure impact the latent heat of fusion [33]. Overall, the thermal stability of the treated HP $\beta$-CD sample was increased significantly compared to the control sample.
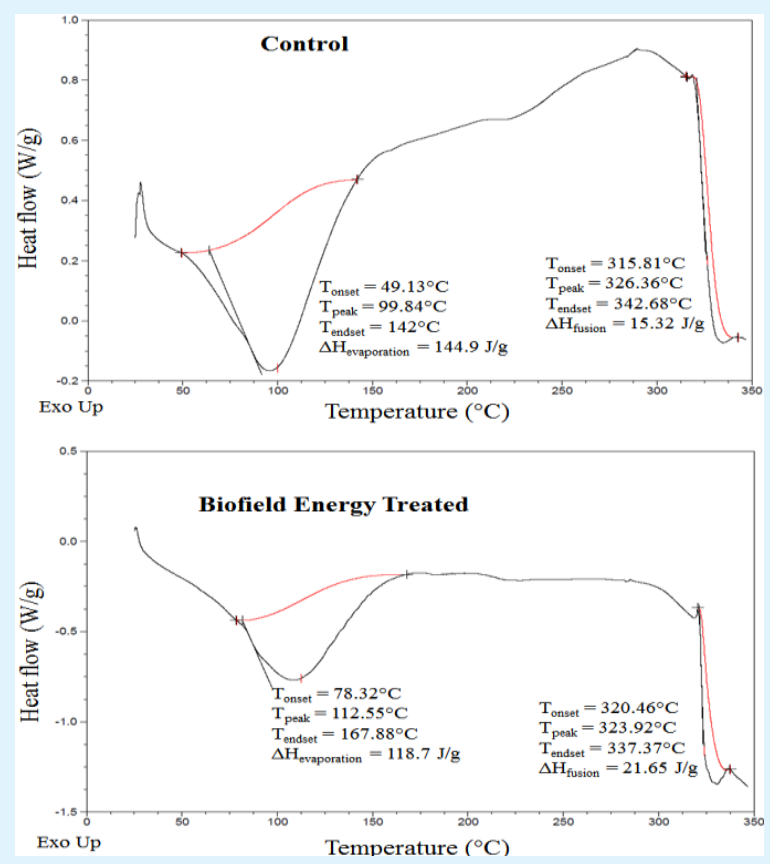

Figure 2: DSC thermograms of the control and the Biofield Energy Treated HP $\beta$-CD sample.

\begin{tabular}{|c|c|c|c|c|}
\hline \multirow{2}{*}{ Sample } & \multicolumn{2}{|c|}{ Melting point $\left({ }^{\circ} \mathbf{C}\right)$} & \multicolumn{2}{|c|}{$\Delta \mathbf{H}(\mathrm{J} / \mathrm{g})$} \\
\cline { 2 - 5 } & $\mathbf{1}^{\text {st }}$ Peak & 2 $^{\text {nd }}$ Peak & Evaporation & Melting \\
\hline Control Sample & 99.84 & 326.36 & 144.9 & 15.32 \\
\hline $\begin{array}{c}\text { Biofield Energy } \\
\text { Treated }\end{array}$ & 112.55 & 323.92 & 118.7 & 21.65 \\
\hline \% Change* & 12.73 & -0.75 & -18.08 & 41.32 \\
\hline
\end{tabular}

Table 2: DSC data for both control and the Biofield Energy Treated samples of HP $\beta$-CD sample.

$\Delta \mathrm{H}$ : Latent heat of evaporation/fusion, *denotes the percentage change of the Biofield Energy Treated HP $\beta$-CD with respect to the control sample.

\section{Thermal Gravimetric Analysis (TGA)/ Differential Thermo Gravimetric Analysis (DTG)}

The TGA/DTG thermograms of the control and the treated HP $\beta$-CD samples showed two steps of the degradation process in the thermograms (Figures $3 \& 4$ ). The total weight loss in the treated HP $\beta$-CD sample $(95.62 \%)$ was decreased by $0.61 \%$ compared to the control sample (96.21\%). Therefore, the residue amount was $15.53 \%$ more in the Biofield Energy Treated HP $\beta$-CD sample compared to the control sample (Table 3).

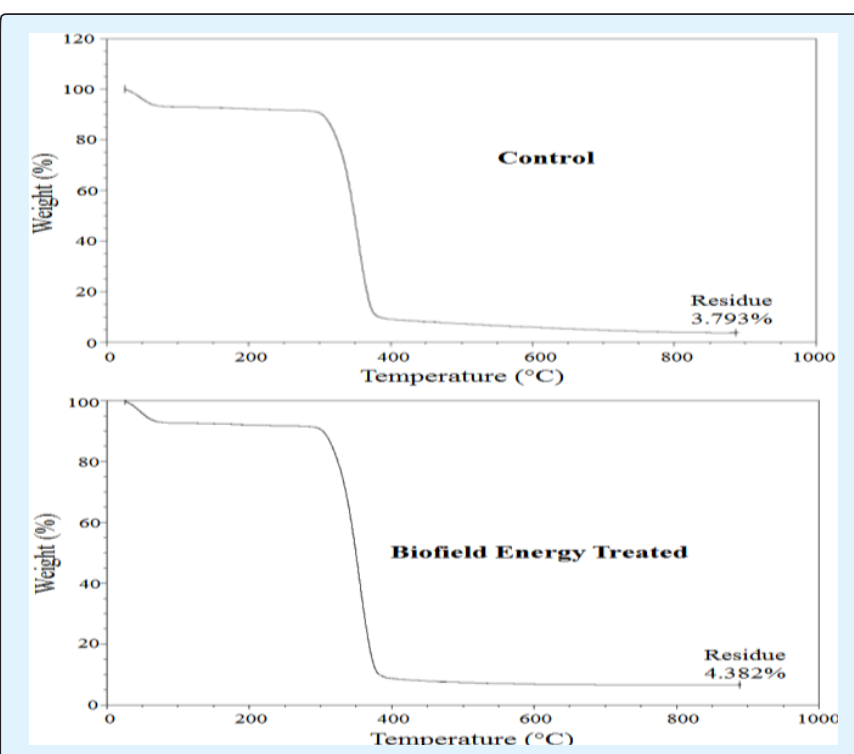

Figure 3: TGA thermograms of the control and the Biofield Energy Treated HP $\beta$-CD sample.

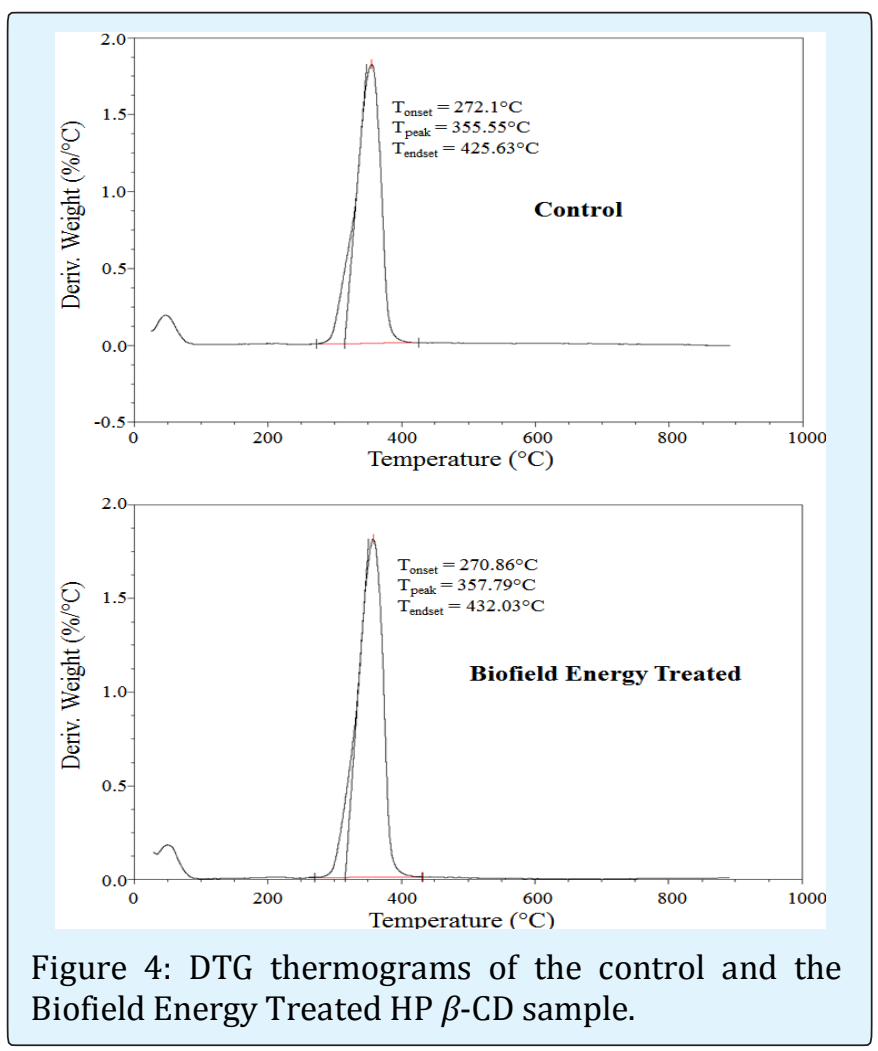




\section{Medicinal \& Analytical Chemistry International Journal}

\begin{tabular}{|c|c|c|c|}
\hline \multirow{2}{*}{ Sample } & \multicolumn{2}{|c|}{ TGA } & DTG \\
\cline { 2 - 4 } & $\begin{array}{c}\text { Total weight } \\
\text { loss (\%) }\end{array}$ & Residue \% & $\left.\mathbf{T}_{\max } \mathbf{~}^{\circ} \mathbf{C}\right)$ \\
\hline Control & 96.21 & 3.79 & 355.55 \\
\hline $\begin{array}{c}\text { Biofield Energy } \\
\text { Treated }\end{array}$ & 95.62 & 4.38 & 357.79 \\
\hline \% Change & -0.61 & 15.53 & 0.63 \\
\hline
\end{tabular}

Table 3: TGA/DTG data of the control and the Biofield Energy Treated samples of HP $\beta$-CD sample.

*denotes the percentage change of the Biofield Energy Treated HP $\beta$-CD sample with respect to the control sample, $\mathrm{T}_{\max }=$ the temperature at which maximum weight loss takes place in TG or peak temperature in DTG.

The DTG thermograms (Figure 4) of the Biofield Energy Treated HP $\beta$-CD showed the maximum thermal degradation temperature $\left(\mathrm{T}_{\max }\right)$ almost close to the control sample. Overall, TGA/DTG thermal analysis revealed that the thermal stability of the Biofield Energy Treated HP $\beta$-CD sample was significantly increased compared with the control sample.

\section{Conclusion}

The Consciousness Energy Healing Treatment has the significant impact on the particle size, surface area, and thermal properties of HP $\beta$-CD. The particle size values were decreased by $2.16 \%\left(\mathrm{~d}_{10}\right), 0.65 \%\left(\mathrm{~d}_{50}\right), 1.22 \%\left(\mathrm{~d}_{90}\right)$, and $1 \%\{\mathrm{D}(4,3)\}$; thus, the specific surface area was increased by $1.27 \%$ in the Biofield Energy Treated HP $\beta$ $\mathrm{CD}$ compared to the control sample. The latent heat of fusion $\left(\Delta \mathrm{H}_{\text {fusion }}\right)$ of the Biofield Energy Treated HP $\beta$-CD was significantly increased by $41.32 \%$ compared with the control sample. The total weight loss was decreased; however, the residue amount was significantly increased by $15.53 \%$ of the Biofield Energy Treated sample compared to the control sample. The results indicated that the Consciousness Energy Healing Treatment produced a new form of HP $\beta$-CD which may show better solubility, dissolution rate, absorption, bioavailability, and more thermal stability compared to the control sample. The Trivedi Effect ${ }^{\circledR}$-Consciousness Energy Healing Treated HP $\beta$-CD would be more useful for the improvement of solubility of the lipophilic drugs, stabilize volatile and unstable compounds, preparation of cholesterol free food products, weight loss supplements, anti-obesity medication and also fulfill the demand of other manufacturing industries which use it as a raw material.

\section{Acknowledgement}

The authors are grateful to Central Leather Research Institute, SIPRA Lab. Ltd., Trivedi Science, Trivedi Global, Inc., Trivedi Testimonials, and Trivedi Master Wellness for their assistance and support during this work.

\section{References}

1. https://en.wikipedia.org/wiki/Cyclodextrin. Retrieved 22-06-2018.

2. https://www.sigmaaldrich.com/catalog/product/sig $\mathrm{ma} / \mathrm{h} 107$ ?lang=en\&region=IN. Retrieved 22-06-2018.

3. Morrison PWJ, Connon CJ, Khutoryanskiy VV (2013) Cyclodextrin-mediated enhancement of riboflavin solubility and corneal permeability. Mol Pharmaceutics 10(2): 756-762.

4. Artiss JD, Brogan K, Brucal M, Moghaddam M, Jen KL (2006) The effects of a new soluble dietary fiber on weight gain and selected blood parameters in rats. Metabolism. 55(2): 195-202.

5. Grunberger G, Jen KL, Artiss JD (2007) The benefits of early intervention in obese diabetic patients with FBCx: A new dietary fibre. Diabetes Metab Res Rev 23(1): 56-62.

6. Bouchal F, Skiba M, Chaffai N, Hallouard F, Fatmi S, et al. (2015) Fast dissolving cyclodextrin complex of piroxicam in solid dispersion Part I: Influence of $\beta$-CD and $\mathrm{HP} \beta-\mathrm{CD}$ on the dissolution rate of piroxicam. Int J Pharm 478(2): 625-632.

7. Marcolino VA, Zanin GM, Durrant LR, Benassi MDT, Matioli G (2011) Interaction of curcumin and bixin with $\beta$-cyclodextrin: Complexation methods, stability, and applications in food. J Agric Food Chem 59(7): 3348-3357.

8. Motoyama A, Suzuki A, Shirota O, Namba R (2002) Direct determination of pindolol enantiomers in human serum by column-switching LC-MS/MS using a phenylcarbamate- $\beta$-cyclodextrin chiral column. J Pharm Biomed Anal 28(1): 97-106.

9. Trivedi MK, Branton A, Trivedi D, Shettigar H, Bairwa $\mathrm{K}$, et al. (2015) Fourier transform infrared and ultraviolet-visible spectroscopic characterization of biofield treated salicylic acid and sparfloxacin. Nat Prod Chem Res 3: 186.
Nayak G, et al. Physicochemical and Thermal Properties of Consciousness Energy Healing Treated Hydroxypropyl $\beta$-Cyclodextrin. Med \& Analy Chem Int J 2018, 2(3): 000124. 


\section{Medicinal \& Analytical Chemistry International Journal}

10. Nayak G, Trivedi MK, Branton A, Trivedi D, Jana S (2018) The energy of consciousness healing treatment: Impact on physicochemical and thermal properties of l-tryptophan. Journal of Food Science and Technology 5(3): 95-106.

11. Nayak G, Trivedi MK, Branton A, Trivedi D, Jana S (2018) Evaluation of the Effect of Consciousness Energy Healing Treatment on the Physicochemical and Thermal Properties of Selenium. Journal of New Developments in Chemistry 2(1): 13-23.

12. Branton A, Jana S (2017) Effect of The biofield energy healing treatment on the pharmacokinetics of 25hydroxyvitamin $\mathrm{D}_{3}\left[25(\mathrm{OH}) \mathrm{D}_{3}\right]$ in rats after a single oral dose of vitamin $\mathrm{D}_{3}$. American Journal of Pharmacology and Phytotherapy 2(1): 11-18.

13. Trivedi MK, Mohan TRR (2016) Biofield energy signals, energy transmission and neutrinos. American Journal of Modern Physics 5(6): 172-176.

14. Rubik B, Muehsam D, Hammerschlag R, Jain S (2015) Biofield science and healing: history, terminology, and concepts. Glob Adv Health Med 4: 8-14.

15. Oschman J (2003) Energy medicine in therapeutics and human performance. Philadelphia: Butterworth Heinemann 1-12.

16. Barnes PM, Bloom B, Nahin RL (2008) Complementary and alternative medicine use among adults and children: United States, 2007. Natl Health Stat Report 12: 1-23.

17. Koithan M (2009) Introducing complementary and alternative therapies. J Nurse Pract 5(1): 18-20.

18. Trivedi $\mathrm{MK}$, Tallapragada RM, Branton A, Trivedi D, Nayak G, et al. (2015) Physicochemical and atomic characterization of silver powder after biofield treatment. J Bioengineer Biomedical Sci 5: 165.

19. Trivedi MK, Branton A, Trivedi D, Nayak G, Panda P, Jana $S$ (2016) Isotopic abundance ratio analysis of 1,2,3-trimethoxybenzene (TMB) after biofield energy treatment (The Trivedi Effect ${ }^{\circledR}$ ) using gas chromatography-mass spectrometry. American Journal of Applied Chemistry 4(4): 132-140.

20. Nayak G, Altekar N (2015) Effect of a biofield treatment on plant growth and adaptation. J Environ Health Sci 1(2): 1-9.
21. Trivedi MK, Branton A, Trivedi D, Shettigar H, Nayak G, et al. (2015) Antibiogram, biochemical reactions and genotyping characterization of biofield treated Staphylococcus aureus. American Journal of BioScience 3(6): 212-220.

22. Trivedi MK, Branton A, Trivedi D, Nayak G, Gangwar M, et al. (2015) Agronomic characteristics, growth analysis, and yield response of biofield treated mustard, cowpea, horse gram, and groundnuts. International Journal of Genetics and Genomics 3(6): 74-80.

23. Trivedi MK, Patil S, Shettigar H, Mondal SC, Jana S (2015) The potential impact of biofield treatment on human brain tumor cells: A time-lapse video microscopy. J Integr Oncol 4: 141.

24. Trivedi MK, Sethi KK, Panda P, Jana S (2017) A comprehensive physicochemical, thermal, and spectroscopic characterization of zinc (II) chloride using X-ray diffraction, particle size distribution, differential scanning calorimetry, thermogravimetric analysis/differential thermogravimetric analysis, ultraviolet-visible, and Fourier transform-infrared spectroscopy. Int J Pharm Investig 7(1): 33-40.

25. Trivedi MK, Sethi KK, Panda P, Jana S (2017) Physicochemical, thermal and spectroscopic characterization of sodium selenate using XRD, PSD, DSC, TGA/DTG, UV-vis, and FT-IR. Marmara Pharmaceutical Journal 21(2): 311-318.

26. (1997) Desktop X-ray Diffractometer "MiniFlex+". The Rigaku Journal 14(1): 29-36.

27. Zhang T, Paluch K, Scalabrino G, Frankish N, Healy AM, et al. (2015) Molecular structure studies of (1S,2S)-2-benzyl-2,3-dihydro-2-(1Hinden-2-yl)-1Hinden-1-ol. J Mol Struct 1083: 286-299.

28. Langford JI, Wilson AJC (1978) Scherrer after sixty years: A survey and some new results in the determination of crystallite size. J Appl Cryst 11(2): 102-113.

29. Chereson R (2009) Bioavailability, bioequivalence, and drug selection. In: Makoid CM, Vuchetich PJ, Banakar UV (Eds.), Basic pharmacokinetics $1^{\text {st }}$ (Edn.), Pharmaceutical Press, London.

30. Khadka P, Ro J, Kim H, Kim I, Kim JT, et al. (2014) Pharmaceutical particle technologies: An approach to
Nayak G, et al. Physicochemical and Thermal Properties of Consciousness Energy Healing Treated Hydroxypropyl $\beta$-Cyclodextrin. Med \& Analy Chem Int J 2018, 2(3): 000124. 


\section{Medicinal \& Analytical Chemistry International Journal}

improve drug solubility, dissolution and bioavailability. Asian J Pharm Sci 9(6): 304-316.

31. Buckton G, Beezer AE (1992) The relationship between particle size and solubility. Int J Pharmaceutics 82(3): 7-10.

32. Moriwaki C, Costa GL, Ferracini CN, de Moraes FF, Zanin GM, et al. (2008) Enhancement of solubility of
Albendazole by complexation with $\beta$-cyclodextrin. Brazilian Journal of Chemical Engineering 25(2): 255267.

33. Zhao Z, Xie M, Li Y, Chen A, Li G, et al. (2015) Formation of curcumin nanoparticles via solutionenhanced dispersion by supercritical $\mathrm{CO}_{2}$. Int $\mathrm{J}$ Nanomedicine 10: 3171-3181. 